\title{
Value Chain for Strategic Management Accounting in Higher Education
}

\author{
Khaled Abed Hutaibat \\ Accounting Department, Mu'tah University \\ P.O. Box 2116, Tla Al-Ali (11953), Amman, Jordan \\ E-mail: Hutaibat@hotmail.com
}

Received: May 18, 2011

doi:10.5539/ijbm.v6n11p206

\author{
Accepted: June 20, $2011 \quad$ Published: November 1, 2011 \\ URL: http://dx.doi.org/10.5539/ijbm.v6n11p206
}

\begin{abstract}
The purpose of the paper is to propose a value chain model for the Higher Education context. The findings are derived from a comparative study of English and Jordanian Higher Education. The model is supportive of strategic management and a strategic cost analysis, if the appropriate information is provided and accessible. Access was one limitation in this study, which is why no cost analysis can be reported. Initial data collection took place in the Business/Management division of an "old" English University. Then, the developed model was tested in a different, the Jordanian, environment, in order to determine its general applicability. All participants of the three divisions were interviewed and qualitative methods were used to analyse the data. Thus, the model was developed by analysing empirical data, and using suggested models from two different studies. It offers a contribution to identifying competitive advantage in Higher Education on the basis of resources and capacities, in line with the resource-based theory, which presents the theoretical context of this study. Furthermore, it seeks to contribute a new approach to the value chain model for Higher Education institutions. The value chain approach is considered most useful for strategic management and planning. As the first part of study was undertaken in England, and then applicability of the model was tested in Jordan, findings are generalisable.
\end{abstract}

Keywords: Value chain, Strategic management accounting, Higher education, Resource-based theory

\section{Introduction}

In recent years the Higher Education (HE) sector has experienced various changes and developments, such as increased competition, globalisation and limited funding resources. The need for strategy, strategic management and strategic management accounting (SMA) has become apparent in HE sectors. For example in Britain, this was intensified through the governmental White Paper from 2003 (DfES, 2003) and the 'Innovation Nation' White Paper from 2008 (DIUS, 2008), and recent decisions to further increase tuition fees (BBC, 2010). These governmental White Papers focussed on HE by outlining how research is funded in the UK, how innovation is supposed to be supported and what kind of research is treated favourably. In general, these papers serve to tighten the sector and increase competition considerably. In Jordan, the HE sector experiences severe constraints due to lack of financial resources and academic members of staff, who are often attracted away to neighbouring countries. Although the current study focuses on England and Jordan, all HE sectors are experiencing similar issues due to globalisation and technological advancements (Paul, 2005). Thus, this article addresses a broad target audience.

This study seeks to contribute a comprehensive value chain model for the HE sector, developed inductively on the basis of empirical data. The latter point ensures that the model is based on the actual academic reality and academia's needs. This was identified as a gap in the published literature. Groves et al. (1997) developed a similar model but did not state that they based it on empirical data. While the application of their model was initially this study's objective, it transpired that their model in fact does not reflect the academic reality of many disciplines. In particular, not considering academic staff as a major resource and critical factor in their model is considered a major gap, which this article seeks to close, and thus contributes a comprehensive model to the extant literature. In focussing on what resources institutions have available that add value through providing a competitive advantage or through reducing organisational weaknesses, this study takes a resource-based theoretical approach. The resource-based theory or view of an organisation suggests that an organisation has to have access to resources that are rare and as a result valuable to the organisation (Barney, 1991). The best case is if resources are also the source of an organisation's competitive advantage, meaning they are inimitable (Barney, 1991). This theoretical background sets the context of the current study, as the concept of value chain analysis supports the approach of the resource-based theory. An organisation should identify its resources and capabilities, and consequently its distinctive competencies, and on that basis decide whether it should follow a cost or differentiation strategy, and finally undertake its value chain analysis accordingly (Henry, 2011).

Following this introduction, the relevant literature and then the development of the proposed value chain model will be discussed. Research methodology and methods will be addressed, and finally findings will be outlined 
and discussed. The findings section is broken down into outlining the academic division's context and background, its main concerns, and its principal academic operations. Furthermore, the developed value chain will be outlined, and discussed in detail. Recommendations for undertaking a value chain cost analysis are made. The conclusion addresses the main points of the findings, and reinforces the usefulness of the value chain in the HE setting.

\section{Literature review}

Higher Education has undergone significant changes in the recent past (Paul, 2005). In the UK, the trebling of tuition fees in 2006 and the planned additional rise by 2013 (Grimston, 2009) is a strong indicator for the increased 'business' approach to education, with the 'student as customer' notion getting stronger. Similarly, the tightening of research funds, the concentration of these funds on research-accomplished institutions only and additional funds for innovative research and education (Wilsdon, 2008), asks for institutions to deliberately focus on what they are good at or choose a specific direction they would like to pursue. Additionally, the White Paper notes the need for aligning management and accounting systems to the increased focus on innovation (DIUS, 2008, p. 72). This notion is supported by strategic management thinking, and strategic management accounting practices and tools (see for instance, Bromwich, 1990; Kaplan, 1984; Shank, 1989; Simmonds, 1981; Ward, 1992; Wilson, 1995). From a theoretical standpoint, resource-based theory focuses on the identification of value-adding, rare resources in a firm, in order to be more successful than their competing organisations (Grant, 1991). The resource-based theory, or resource-based view, says that firstly resources and capabilities of an organisation need to be identified before the appropriate strategy can be determined and implemented. Competitive advantage arises when resources are not only rare but also inimitable, thus making the organisation very valuable to customers (Grant, 1991; Kraaijenbrink et al., 2010). The resource-based theory is considered one of the most influential theoretical frameworks with regard to understanding strategic management (Barney et al., 2001), and it has been considered in an accounting context (Bowman and Toms, 2010; Toms, 2010), thus it was chosen as the theoretical background of the current study. SMA serves as a financial support system of strategic management (Simmonds, 1981), including formation, implementation and control of organisational strategy, and the use of strategy-relevant resources. The purpose of this article is to develop an adopted value chain model for HE institutions, focussing on HE - relevant resources and capabilities. HE institutions rely greatly on human capital resources that in many disciplines are rare and often, based on individual abilities, have inimitable knowledge, ideas and abilities. The resource-based theory therefore requires focussing on the organisation's resources and capabilities, and how they are used to develop and maintain competitive advantage (Barney, 1991; Barney et al., 2001), whereas the value chain provides a useful tool to operationalize and implement the generic strategy, chosen on the basis of resources and capabilities, and create value due to inimitable, distinctive competencies (Porter, 1985, Shank and Govindarajan, $1992 \mathrm{a}$ and b).

In particular, Porter $(1980,1985,1990,1991)$ has published several works that matter greatly in the context of strategic management and identification of competitive advantage, including publications on competitive strategy (1980), on five forces (1980) and the diamond model (1990), and finally on the value chain (1985). He (1980, 1991) adopts a design school stance with regard to strategy (Mintzberg, 1990), as "strategy is the act of aligning a company and its environment" (Porter, 1991, p. 4). Succeeding and maintain that success require clearly defined goals and objectives, awareness of one's market position, internal strengths and weaknesses, external opportunities and threats, and the ability to exploit core competences. Porter suggests two generic strategies, cost leadership and product differentiation (Porter, 1985). Cost leadership aims at having the lowest cost compared to competitors, whereas a differentiation strategy suggests offering something unique and different to competitors. Based on Porter's approach, Shank and Govindarajan (1993) developed a similar idea, which they refer to as Strategic Cost Management (SCM).

SCM is defined as "the managerial use of cost information explicitly directed at one or more of the four stages of the strategic management cycle" (Shank, 1989, p. 50). Three SCM underlying concepts have been identified: value chain analysis, strategic positioning analysis and cost driver analysis (Shank, 1989; Shank and Govindarajan, 1992 a and b, 1993; Shank, 1996), which in combination are suggested to produce strategy-relevant cost data. However, Shank and Govindarajan (1993) advocate as most useful for cost analysis the value chain with a strong external focus as most useful for a cost analysis. Furthermore, Tomkins and Carr (1996) undertook a study in 51 international firms to investigate whether these concepts are being applied, and found that the most successful firms where those that focussed on the value chain and competitive advantage analysis.

Porter (1985) developed the value chain in order to identify core competences and explain cost behaviour patterns, according to the chosen generic strategy. Furthermore it can be used to identify the interrelationships between value-creating activities, based on what customers rank most highly. Value is the basis of the analysis, not cost, as in cases of differentiation costs might be kept high on purpose (Porter, 1985). The scope of the value chain is to extend beyond organizational borders, and take linkages between suppliers and customers into account (Shank and Govindarajan, 1992a). Furthermore, sustainable competitive advantages, that a firm has created, are identified through a value chain analysis. A competitive advantage usually utilises scarce resources and is not easily imitable, and are greatly valued by customers (Shank and Govindarajan, 1992a).

Recent research studies have reported on the applicability of the value chain model. Anderson (2007) uses value chain analysis to advance strategic cost management, by introducing a separation into structural and executional 
cost management on the basis of value chain activities. Cinquini and Tenucci (2010) investigate the use of a variety of strategic management accounting practices, including value chain analysis. They find that the value chain is indeed applied in practice, with varying degrees of popularity. Bardy (2006) identifies new challenges for management accountants, and suggests that interlocking between an organisation's value chain activities and customer/supplier connections is the management accountant's domain. They should be actively involved in managing these relationships. Cadez and Guilding (2007) research the use of various strategic management accounting techniques in Slovenia, and find that, within the group of 'costing' practices, value chain costing is ranked second, thus transpired as known and applied in the practical context. Elloumi (2004) discusses value chain analysis in the context of universities that operate online. The author follows Porter's suggested activities and seeks to group universities' activities accordingly, but at the end of the chapter introduces the value chain of Athabasca University, which has been adapted to reflect specific institution's academic undertakings. However, a general model of universities was not developed.

In fact, Porter developed the value chain originally for private sector organisations, and Groves et al. (1997) amended the model to fit the HE context. The model is illustrated below in Figure 1. Their approach is based on their amended three-fold version of generic strategies: lower cost, higher quality and differentiation (1997, $\mathrm{p}$. 302).

\section{Insert Figure 1 - here}

Groves et al. (1997) split the primary activities into a teaching and research stream, and a third 'intermediate' dimension was added which refers to income-generating activities. Secondary or support activities refer to what a university has to offer as the model addresses the institution as a whole. The application of the value chain takes place in several stages. Firstly, primary and secondary activities need to be identified (Groves et al., 1997). The institution needs to determine with which activities their competitive advantage is associated. For a cost analysis, costs should be assigned to the activities, and should be adjusted and altered according to competitive advantage activities (Groves et al., 1997).

Von Alberti (2003) based her developed models on Groves et al. (1997) but made several important changes. Firstly, members of staff are not taken as a given but are considered an important resource that is rather scare in certain fields. Her study focussed on a Management School, and she found that this is one of the disciplines that have severe difficulties acquiring and retaining qualified academics. Secondly, she changed some assumptions of the generic strategies, as Groves et al. (1997) considered quality a choice and Von Alberti (2003) suggests quality is not an option but an underlying notion in HE. She developed three value chains, which address three different operations: research, teaching and enterprise. The latter refers to consultancy, research-related spin-offs and other industry-related projects. The current study will incorporate all operational activities into one model, as three models are impractical to apply in practice.

When developing a value chain, the activities that correspond to the model's outline have to be identified, and the value chain contributes to the identification of competitive advantage. The activities that create the competitive advantage are dealt with according to the strategic choice the institution has made. In case of the University value chain, Groves et al. (1997) suggest broad and narrow target strategies based on lower cost, higher quality and differentiation. The value chain can also contribute to cost management because the activities that support and/ or create the competitive advantage could be given prevalence regarding financial funds. Groves et al.'s (1997) argument for Porter's generic strategies and value chain is that these can support making strategic decisions for the institution, when adapted to the HE context. The generic strategies offer a typology for deciding in which direction to go, and the value chain identifies the activities that should receive the most focus (Groves et al., 1997). Von Alberti (2003) did not explicitly test Groves et al.'s (1997) model but the empirical analysis resulted in an amendment of the model. The author identified that Groves et al.'s (1997) model had shortcomings that did not reflect the empirical findings.

The value chain is considered a valid tool for identifying, managing and costing competitive advantage, and the HE sector has become increasingly more competitive. Thus, institutions have to focus their managerial and financial management practices on identifying and maintaining their competitive advantage, or in some cases have to develop such advantage. This warrants the use of models and techniques, such as the value chain, in HE.

The initial research objective of this article was to test the applicability of previously developed value chain models for HE (Von Alberti, 2003; Groves et al, 1997) but it transpired from the empirical analysis that the models needed to be amended. During the analysis, it transpired that few but fundamental changes were sufficient. To this end, empirical data was collected to test the relevance of Groves et al.'s (1997) and Von Alberti's (2003) model, and was used to explain amendments made to these authors' HE value chains. Key limitations of their models will be addressed as part of the findings. Particular issues are the quality strategy as a separate choice and the assumption of staff as a given resource, when in fact academics are as much to be 'acquired' as students. These findings support Von Alberti's (2003) suggestions. Despite arising from a case study undertaken in an English institution, the developed value chain model transcends beyond those HE sectors. The investigation in the Jordanian context serves to ensure this general applicability.

\section{Case study and research approach}

This study was undertaken in order to develop a value chain model for HE institutions, but an evaluation and amendment of Groves et al.'s (1997) model transpired as sufficient. This was done on the basis of one division 
of a research-focussed English HE institution, as developing a value chain for the whole institution was not possible, due to lack of access, and the data from one division gave enough insight to evaluate and amend the researched model. One division was focussed on as a representative for the others, and the practicability of the analysis in practice was tested. The chosen academic division focuses on accounting, finance and management. The argument for an academic division is that the first focus of competitive advantage in a HE institution is an academic one. This is particularly relevant in this institution as it is one of the 'old' institutions, which traditionally focus on research. Recently, education has become more important, considering aspects such as teaching quality and student experience. The model is evaluated and amended based on the researched division but is suggested for application in other divisional contexts.

The applicability of the model is then discussed in corresponding Jordanian divisions of three different public institutions, in order to ensure the model's generalisability. Jordan was chosen to test the applicability in an emerging country context, and because $\mathrm{HE}$ is an important factor of the Jordanian economy. Choosing a different context enables the researcher to test the model's robustness and generalisability. The Jordanian context is teaching-focussed in all public and private institutions, whereas the English division is research-focussed. Also this difference allows for testing beyond the original case context.

\subsection{Divisional contexts}

The initial study took place in an 'old', research-focussed English university and was undertaken in the Management School of that institution. Prior to the study, the institution's strategic objectives had been refocused to include education in addition to research. Traditionally, old universities focus more on research, whereas new universities, meaning polytechnics-turned-universities, focus more on education. Recently, research-focussed institutions have diversified by paying attention to education-related issues, such as student centredness and student satisfaction, high quality education, and a student support system for educational and personal issues.

The combination of pursuing first class, exploratory and ground-breaking research, and seeking to provide high-quality education through a innovative and long-proven teaching and learning practices, was the primary reason for undertaking the study in the particular institution, since the value chain for HE institutions includes both research and education. Furthermore, access is an important factor as far as qualitative studies are concerned, as not every institution might like to share its data and let its employees be interviewed on how they perceive the organisation or institution. Access was a major factor when it came to selecting the division, as only the Management School agreed to participate in the study. In addition, the Management School is deemed appropriate, since the concept of the value chain was developed in a Business School, thus it was expected that interviewees could relate to the topic and that the division was interested in developing the model and the results. Access also played a major factor when it came to selecting the Jordanian divisions. Jordan has seven public and eight private institutions. Access was obtained to only three public institutions.

At the time of the study the English division offered a range of courses, of which fifteen were undergraduate and thirteen were postgraduate courses, addressing marketing, banking, finance, risk management, accounting, management, human resources and entrepreneurship. Some of these courses are undertaken in collaboration with other divisions. The origins of the institution lie in a focus on research, but recently the teaching and education profile has become stronger across all divisions. At the time of study, the researched division had adapted the research focus but the nature of the discipline provides greater revenues through teaching, in particular overseas postgraduate students. Thus, regarding teaching, the divisional emphasis is on postgraduate students, with the majority being taught postgraduate and increasingly more research students. Undergraduate student numbers are maintained at a steady state of 400 students every academic year. The division employed 50 academic and 20 support staff at that point. Research is homogeneously grouped according to disciplines, for instance accounting academics formed a research group. Each group was run by an established professor but all researchers were working in their chosen field of study, i.e. financial accounting, taxation, accounting history.

In the case of the Jordanian institutions, three public institutions were chosen, as they correspond to the English institution in mission and approach, e.g. no profit incentive, contribution to society, research and teaching considerations. A significant difference between the English and the Jordanian system is that teaching is far more dominant than research in Jordan. Academics' workload is determined by the courses they teach and, if so, the administrative work they do. Research is a 'in your own time' activity with no pressuring expectations other than getting promoted to the next level within ten years of accepting an academic position. Revenues are mainly earned from tuition fees and from governmental subsidies. The need for such subsidies has to be clearly identified and explained. A further significant difference is the structural organisation of the various divisions. In all three Jordanian institutions, management divisions are grouped into faculties, as opposed to schools in a faculty as it is the case with the English division. Furthermore, administration is mainly centralised, with the only administrative support in academic divisions being secretaries for deans and heads of departments. This is the case in each of three investigated divisions but the three Jordanian institutions vary greatly from each other. Jordanian Institution Number 1 is the oldest of the three, and has a large management division. It addresses all management-related subjects, including management, marketing, accounting, finance and economics, which are organised into respective departments. At the time of research, the faculty had around 3,200 students registered and 44 academics employed. All academic members of staff were addressed for interviews but only three, located in three different departments, agreed to take part. Two held administrative posts at the time. Institution 
Number 2 is much younger but similar in size and range. It has around 3,000 registered students but only employs around 30 academics. The respective faculty is split into three departments offering the same range of subjects as the management faculty in Institution 1. Two members of staff agreed to be interviewed, of which one previously held an administrative position. Both members of staff came from the same department. Institution Number 3 has also only recently been founded. Its student and staff numbers are significantly lower than Institution Number 1 and 2, in the corresponding faculty. At the time of the study, this faculty had only 500 students registered and 15 academics in employment. It is divided into three departments that offer specialised courses in management, accounting and logistics. In this institution only one academic staff member could be interviewed who held two administrative posts at the time.

\subsection{Research approach}

The theoretical context of this study is resource-based theory, which suggests that certain resources and capabilities are needed to determine which generic strategy to adopt. This generic strategy is then implemented through value creation by way of a value chain analysis (Henry, 2011). HE is an internationally competitive sector, which requires identifying, acquiring and focussing resources in order to maintain a top research and education position in the global market. The value chain analysis seeks to identify value creation in order to achieve such top position through an adopted.

The adopted methodology is action research, which is placed in the interpretive paradigm (Hussey and Hussey, 1997). The aim of the research is to address problems in an existing setting, hence to address 'real-world' situations, and to develop guidance for actions that produce desired outcomes (Avison et al., 1999). The researcher seeks to contribute to science (Hussey and Hussey, 1997), which differentiates it from a pure consultancy project (Avison et al., 1999). Action research engages the researcher with the objective to "develop new solutions that alter existing practice" and then test its feasibility (Kaplan, 1998, p. 89). Denscombe (1998) considers action research a "strategy for social research rather than a specific method" (p. 58), because it takes up on the holistic notion but does not constrain to any "means for data collection" (p. 58). Denscombe (1998) has identified "four defining characteristics of action research" (p. 57), which are "practical, change, cyclical process and participation" (p. 57/58). This study deals with a practical problem, and change was attempted but the implementation of the value chain did not take place during the time of this study. Staff members reflected on the developed model and some considered aspects of it a useful concept.

Several types of data were collected for the value chain project. Regarding the English division, an in-depth study was commenced on the division's eight research and four teaching disciplines and groupings. Semi-structured interviews were undertaken in order to identify the activities of the division. Documents, such as strategic plans, education and research plans, and financial statements were used for the same purpose and later on to support the cost analysis. The strategic plan was outlined according to the institutional strategic planning layout. Both staff and students were interviewed in order to identify the division's competitive advantages. The sample size covered eight staff members and ten students. Table 1 outlines the composition of interviewees.

\section{Insert Table 1 - here}

Student interviewees were chosen on the basis of who responded to an ad posted in the lobby of the division. Members of staff were specifically identified based on positions they held in the division - these included all full professors, who usually held administrative as well as academic positions, the head of the school, and administrative staff in key positions, such as the learning and teaching officer. With the exception of one professor, everyone agreed to be interviewed. Furthermore, junior academic staff was also approached but only one member of staff agreed to take part in the study. As both groups of interviewees wanted to remain anonymous, references to interviewees are stated as 'academic staff member', 'support staff member' or 'student'. Average length of interviews with members of staff was around one hour; average length of interviews with students was around thirty minutes. Research and educational plans included both strategic ambitions, as outlined in the strategic plan, and operational aspects, as outlined in annual operation statements. Cost data was obtained from historical financial statements, budgets, and staff and student records.

In the Jordanian divisions, all members of staff were approached but as mentioned above, in Institution 1 three academic staff members, in Institution 2 two academic staff members and in Institution 3 one academic staff member accepted to take part. They were interviewed using the same questions as were used when researching the English division but at the end of the interview they were shown the developed value chain model in order to determine whether it reflects their institutional context. The interview data allowed for the identification of the English division's primary and secondary activities, the competitive advantages and the preliminary cost analysis according to the value chain model. The collected data was analysed according to several analytical styles. Interpretive questions were used, such as where, who, when, why, and what (Stringer, 1999), and problem analysis was applied. This type of analysis looks at the antecedents and consequences of a phenomenon or problem (Stringer, 1999). A number of qualitative analysis methods, suggested by Hussey and Hussey (1997), have been employed, such as keeping understandable records of interviews, coding data in the sense that specific sentences were highlighted in the interview records, and analysing in an on-going process.

\section{Development of the value chain for $\mathrm{HE}$}

The following section outlines the findings of the study. During the analysis, the empirical data was first focussed on, thus it is addressed first in this section. Details of the English and Jordanian divisions are presented, 
then the empirical data analysis that was used to amend and enhance Groves et al. (1997) model, is outlined.

\subsection{Conceptual context and operational activities}

The conceptual context was derived from the empirical data pertaining to the researched divisions. Prior to the development of this study's model, the divisional contexts, strategic foci and operational activities were researched and outlined. Three areas were identified: perception of academic actuality as the context, and research and teaching as activities. Perception of academic actuality comprises the fierceness of the academic world, referring to issues such as the tightness of financial funds, the constant tension between research and teaching (as part of the overall education context), and the difficulties of staff acquisition and retention in subjects where the 'outside' job-market is very competitive. This is akin to Von Alberti's (2003) 'academic reality'.

The activities of research and teaching are the main operational activities and strongly related to major strategic foci in the English division. In the Jordanian divisions, teaching and research are the main operational activities, but teaching is primarily the strategic focus, whereas research is fostered by individual academics' interests and ambitions. Staff is the main asset related to these activities, and being successful and reputable in both requires the best people in their field. Generally in academia, some subjects are very competitive outside of academia, such as business and computer science-related studies, whereas some fields do not have enough positions for applicants, for instance history. Since the division is in the management discipline, it found it difficult to fill its open positions with adequate people and/ or retain the people they employed due to poaching from other institutions. This is the case in the English and the Jordanian divisions. In the Jordanian context, neighbouring countries are mainly responsible for movement of academic staff, because they pay higher salaries. In the English context, the tension between research and education has been increased due to various governmental decisions (BBC, 2010; DfES, 2003) and societal developments which bring education to the fore, due to increases of tuition fees, the demand for a quality student experience and quality teaching, and the increasing notion of the student as a customer/ client. In the Jordanian institutions, the notion of student as customer has increasingly got stronger, in particular in Institution 3 which charges the highest fees of all three. As education is the strongest feature in the academic context, quality education is the major focus of the Jordanian HE sector.

The English division is part of a research-focussed institution, thus has to up-keep its research profile and fulfil the requirements regarding a quality student experience. This is intensified by new research and teaching objectives, and funding input (DIUS, 2008). This creates a constant tension, in particular in cases where members of staff are very outstanding researchers who are willing to take their research elsewhere if they are not given enough time to follow their interests. The Jordanian divisions are part of a teaching-driven system, which creates a tension between education and research for the individual, as they have to publish to get promoted, and the systems requires them to get promoted within a reasonable timeframe of ten years, yet they are not given any time and only limited resources to undertake research. For many academics ten years have passed without actually undertaking much research.

Research plays an important role for all divisions' academic reputation, as was identified by all interviewed academics. Particularly in the English context, despite new tendencies in the HE sector, being part of the top institutions requires excellence regarding research and education. Ultimately, this article argues that the raison d'être of any HE institution is a contribution to society, through furthering one's discipline by undertaking research, and passing on existing and new knowledge to new generations through various educational channels. The 2003 and 2008 English White Papers limit institutions' ability to undertake research with regard to the distribution of research funding, as only distinguished and experienced institutions and researchers will receive financial support for research. The English divisional context requires a high level of research activity, which at the time was considered the main priority.

Teaching stands for the actual class time but also the care outside the class room, for instance the time a lecturer spends with a student discussing their questions, concerns or specific issues. This was identified as part of interviews and was concluded based on interviewees' input. While this could be considered in a wider educational context, members of all divisions referred to 'teaching', including both class time and other activities dealing with students and the subject, thus this term was used for this case study. With regard to all divisional contexts, teaching plays the main role, as a sub-feature of the overall institutional education agenda. Factors such as student experience with regard to living standards, facilities for students' use on campus and the general surroundings of the University are the concern of the institutional management.

Furthermore, in all cases teaching is an important source of income; in the Jordanian context in particular it is the main source of income. In the English division, even a teaching and learning officer had been employed in order to introduce new learning methods, so as to offer students a better learning experience. In the same division, the members of staff experience the tension between research and teaching the most at this level because research is considered the main priority, yet income is from students, thus both operational streams have to be served. In the Jordanian divisions, the tension between research and teaching is experienced at the individual level because, while research does not feature majorly in the institutional and divisional strategic context, academics are expected to publish. They cannot get promoted without publications, ideally at a first class level, yet little commitment can be made due to the teaching and administration workload, and minimal support is available. 


\subsection{Critical success factors}

Several critical success factors were identified at the time, which include permanent and sector-wide issues, such as staff, funding and time. These are critical issues but also relevant resources in order to determine the appropriate strategy and to be competitive in the sector. In the particular disciplinary context, new members of staff are difficult to hire because the world beyond academia has financially more to offer, and competition among institutions and neighbour countries' HE sectors is fierce. "We are glad when we have 10 applications for one opening, and other departments have up to 160 for one opening" (academic staff member B). This makes academic staff a rare resource, and their respective knowledge and abilities in many cases inimitable.

Movement among institutions is a common feature of this discipline. Poaching by other institutions, moving to industry, private universities or Gulf countries' HE sectors for better pay are realistic dangers. Increased competition in the sectors means that all institutions are seeking to hire the top and most promising academics in their field. In England, rules of hiring only when a position is open might lead to a loss of an outstanding post-doctorate fellow due to bureaucracy (academic staff member C). This is not an issue in the Jordanian context, as they seek to seize the chance at hiring a first class academic. Furthermore, Jordanian HE institutions have developed a system that allows them to acquire and retain members of staff for a specific length of time. In order to undertake high quality postgraduate taught and research education, future members of staff have to study abroad, in the US, UK, Canada or Australia. As this is very expensive and only few are able to fund such endeavours, institutions agree to fund their future academics but in return require a mandatory work period, usually a multiple of the actual study time. Nevertheless, members of staff are able to move if they are able to pay off the institution.

Funding is a constant issue because financial resources regarding research are tight. Competition is fierce among members of the English academic community to get the most prestigious type of research funding: the governmental grants, either through participating in a major governmental research project or through applying to the research councils. Getting these grants is an important aspect of research prestige, because they are valued as part of research assessment. Time is the last critical success factor, which refers back to the tension between research and teaching, as members of staff need to manage both activities as successfully as possible. Furthermore, administrative tasks, which arguably consume a large amount of valuable time, are spread among many staff members.

\subsection{Generic strategy and value chain activities}

The value chain is developed in support of strategy and strategic activities, thus the first step is to identify what generic strategy the divisions had adopted. Importantly, the aim of this study was not to arrive at a strategic direction suggestion for any of the three divisions, since that had already been decided upon, but rather provide a practical model, based on a theoretical foundation, which supports the implementation and management of their strategy. Groves et al. (1997) suggest that for HE a quality strategy should be included, which means that quality is also mutually exclusive. They state that there are institutions that 'push for quality' to gain the competitive advantage Porter (1985) considers necessary for being superior in a market. The principles of HE in England and the UK in general suggest that quality is a requirement and necessity, not a choice - it should be one of the implicit goals and foundation of academia regarding both research and education. The same was identified in the Jordanian context. All interviewees stated that quality was expected, not optional, in the context of education. Members of staff added that quality influences institutions' ranking, thus should be an inherent objective. Therefore, the author suggests quality to be the foundation of generic strategies, based on which institutions, divisions and individuals can choose whether they want to adopt cost leadership or differentiation strategies, and a narrow or broad focus as competitive scope. This is in line with Von Alberti's (2003) findings who also identified quality to be an underlying foundation, rather than a concerted choice. Universities that maintain only those subjects they are particularly good at, adopt a narrow focus, identified in interviews as 'multi-versity' concept. Institutions that uphold as many subjects as a "university" comprises, adopt a broad scope.

In order to determine the choice of generic strategy regarding the researched English division, a few points have been perceived as imperative from the data presentation, which are perception of academic actuality, the governmental White Paper, funding and income, research, academic staff and time management. The first two have been chosen because they are strongly influential, external forces. However, they cannot be controlled and thus are underlying concepts. The remaining four are contingent upon the external forces but also upon each other. As these are influenced by the division, they are the main drivers for the generic strategy, which was identified as quality differentiation, based on the collected data. Teaching is also significant but the division sought to raise its profile through research. If this were not achieved the current strategic main priority would have to be revised and shifted. Teaching plays a major role with regard to funding, but is also part of the strategic profile because the overall strategic aim of the institution is to have equally balanced research and teaching quality. This suggests that all aspects are inextricably intertwined, therefore none can be neglected. At the time of the study, the division had begun to change its narrow focus to a broad scope, as it sought to include new subject areas. The broad scope differentiation strategy implies that the division keeps up to date with latest developments in research and teaching. Additionally, it could be a precursor in a particular field, which carries high recognition but might require great expenditure. In the Jordanian divisions, the adopted generic strategies vary. The management faculties of Institution 1 and 2 offer a wide variety of courses and seek to minimise expenses, so adopt a quality lower cost strategy with a broad focus. In Institution 3 the adopted generic strategy 
is quality differentiation with a narrow focus, as only specific and preferably rare programmes are offered.

The empirical data analysis led to the realisation that the activities of the divisions do not correspond exactly to the activities outlined by Groves et al. (1997) and Von Alberti (2003). However, rather than developing a new value chain model for HE, their model was changed according to the division's perception of academic actuality and focus. The objective at the outset had been to develop a new model but in the course of the study it transpired as sufficient to amend and develop Groves et al.'s (1997) and Von Alberti's (2003) models. Following, the amended value chain model is discussed and in the last part of the analysis, the amendments to Groves et al.'s (1997) and Von Alberti's (2003) models are outlined.

\section{Insert Figure 2 - here}

\subsection{Secondary and intermediate activities}

The secondary support activities are discussed upfront, which transpired to be the same in all institutions and divisions. They are collocated according to scope, starting with the broadest background - the University infrastructure, which comprises any services rendered by the centre except academic support, such as general management, finance, human resources and any advisory services for Schools and students. Next are academic support and student services activities like the library, any information technology services, student accommodation, career services and both academic, i.e. for new lecturers, and student, i.e. languages and presentation skills, training courses. Administration and professional services' activities are executed by non-academic staff members, which include student admissions for instance but also finance, human resources, estates and other support activities. Regarding the English division, another activity was included that varies slight from the above, referred to as academic staff support. For research and teaching a mentoring system for new academics has been introduced which is executed by senior academic staff. Additionally a learning and teaching officer has been employed to devise more efficient and effective learning and teaching techniques. This activity does not feature strongly in the Jordanian context, so might be neglected in that context. The intermediate activity is the division's management, which refers mainly to divisional leaders' managing functions, decision-making activities as undertaken by committees, the professional manager involvement in the School, commercial marketing activities, and the divisional administrative positions and tasks that academics have to fulfil. It is considered to be intermediate as it involves academics and support staff and can reduce time for primary activities significantly.

\subsection{Research aspect}

The fundamental concept of research is adding value to society (Groves et al., 1997) but the direct 'customers' are the institution due to enhanced reputation, which attracts scholars, funding, industry and students, and academic journals due to actual publications (Von Alberti, 2003), ultimately addressing the academic and wider community at large.

The value chain developed for Research and Teaching is outlined in Figure 2. Various activities are involved, of which most have been identified during interviews (academic staff member C, E, G) and some have been adopted from Groves et al. (1997, p. 304) and Von Alberti (2003). As first primary activity, 'academic recruitment' has been chosen, because as has been firmly established, perception of academic actuality is of such nature that the academic is an important factor. This activity is applicable for both research and teaching.

The activity refers to recruitment, either through head hunting or applications, and also to links with potential 'suppliers', such as industry, head hunting agencies and other universities. Ultimately, it addresses intellectual capital as core competence. Topic Identification refers to choosing a research topic, and can happen at any point (academic staff member C). Current research might give new ideas for further investigation, but also everyday life entertainment might stimulate to follow a research direction (academic staff member C). This is mainly an internal thinking process for the individual and a communication process for a group. Obtaining funding deals with necessary financial support, either through external governmental and private funding or through internal resource re-allocation horizontal linkages to external bodies are included. Undertaking research refers to the actual work process which differs greatly depending on the kind of research undertaken and the nature of the researcher. In the division research styles differ between group and between individuals. Lastly, two possible activities follow, which are not mutually exclusive.

Marketing for publication stands for the activity of getting research published, so for example contacting academic journals and connections to the latter that can be exploited. Research spin-offs and consultancy refers to using the expertise gained through research and utilising it for commercial purposes, e.g. through providing consultancy services (academic staff member A). In the Jordanian context, training courses are one of the major industry-related outputs due to research interest but also teaching ability. Finally, the activity that is simultaneously on-going next to all other primary activities is managing research, which includes activities such as administering research grants, arranging interviews, hiring research assistants, amongst others.

Internal key competencies which are hard to imitate are researchers' expertise and under certain circumstances style of researching. Expertise is valued very highly in all divisions but the dilemma of retention and acquisition of academic staff threatens key competency development. In case of style of researching, this is particularly applicable in the English division where research is an active operational activity. The division's teamwork and cross-disciplinary potential is very beneficial since differing knowledge of the same subject is combined (academic staff member C). External critical success factors are horizontal and vertical linkages. The former are 
links to organisations that supply to or receive from the division, for instance funding bodies and academic journal editorial boards. The latter refer to collaboration with other institutional divisions and, in addition, to association with competitors, i.e. other academic institutions.

\subsection{Teaching aspect}

Similarly, teaching is considered to add value to society. The core competency of this aspect is also academic expertise. However, the direct customer is industry which will employ students. Students were interviewed to give their input and feedback regarding the divisional teaching performance, but industry has not been added for data collection. However, in the future, percentage of students employed can provide indications of industry's point of view. Employability is part of the wider education realm of institutions, in particular in England because it feeds into the external assessment relating to education and teaching.

Primary activities are divided into two streams, one for students and one for academics, which is connected to the research aspect. Groves et al. (1997) consider student recruitment as a mixture of inbound logistics and marketing, links to 'student suppliers' such as agencies but also industry for postgraduates and any advertising related to courses are included. Academic recruitment as an activity has the same rationale as for research, and in most cases positions are covered by the same person, which the authors tried to illustrate through the overlap of academic recruitment for research and teaching streams. An on-going activity between academics and students is tutoring and supervising, in particular for projects and dissertations, thus it was incorporated as a simultaneous primary activity.

Preparing teaching deals with the review of the actual material. The next activity, providing teaching, is the main point of contact, the actual delivery of material in whichever way, i.e. traditional class contact or e-learning. For the students, this activity is referred to as being taught and learning for instructed students, and researching for research students. The latter are arguably part of the research and teaching aspect, but have been incorporated in this aspect as they are part of the student stream. Examining and being examined activities refer to the next overlap of streams, which mark the end of an academic year, and eventually the students' studies. Career placement refers to any external linkages that students can exploit for employment opportunities. Finally, as with research, managing teaching refers to administrative activities, such as arranging courses, checking on rooms, making sure facilities are accessible.

\subsection{Amendments to Groves et al. 's (1997) value chain model}

Figure 1 illustrates Groves et al.'s (1997) model and Figure 2 illustrates the amended and developed model that transpired from this study. Amendments and development are derived from the analysis of the empirical data. Firstly, quality is considered the foundation of any chosen generic strategy, not a choice, as was suggested by Von Alberti (2003). Secondly, support activities have been amended by summarising student-related activities as academic support and student services, and management and administrative activities as administration and professional services. Furthermore, departmental management is not considered a support activity as academic interviewees felt that it was rather a prominent and time-consuming activity. In the new model it is considered as the intermediate activity and is referred to as divisional management.

Groves et al.'s (1997) primary activities are identified as research and teaching which ultimately add value to society. The academic member of staff needed for these activities is taken for granted, although they were identified as a critical success factor in this study. Members of staff stated that hiring was a difficult procedure with uncertain outcome in the researched case division. Therefore, academic recruitment was considered a crucial activity that can greatly contribute to competitive advantage, as hiring the right member of staff will affect research and teaching output. This also reflects Von Alberti's (2003) findings. Different to Groves et al. (1997), primary activities are related to academics and students. Academics have two parallel, operational activities to focus on: research and teaching. Student activities and academic activities can overlap, as is the case for tutoring and supervision, and they can also ran parallel to each other, like teaching/studying and examining/being examined. The final activity for academics' teaching and students' activities is students' career placement, which is expected to benefit society at large but also industry as a potential employer in particular.

The previously intermediate activity of consultancy and creating spin-offs is now seen as one possible activity resulting from research activity and research and teaching expertise. Especially expertise gained from research leads to a specific teaching expertise. In the Jordanian context, this allows members of staff to teach related training courses. The interview data identified consultancy to stem from research activities, rather than teaching, and has the same importance as achieving publications, reflected as marketing for publications. Finally, beneficiaries/customers have been amended to include not only society (including potential students), but industry, publication media, but also the institution itself and the HE sector. The latter two benefit from students' career placement and excellent publication track records.

\section{Discussion and evaluation of value chain analysis in the Higher Education context}

Strategic management has become a necessity in the public sector due to its increasingly competitive nature (Ferlie, 1992). Especially for English universities, competition has got fiercer through the most recent governmental White Papers on HE (DfES, 2003; DIUS, 2008) and recent decisions to further increase tuition fees (BBC, 2010). In Jordan, financial resources are generally tight, and if institutions want to compete regionally, they have to rely on their competitive advantage and have to manage the critical success factor of academic staff. The resource-based theory served as the theoretical context of the current study, allowing for 
focussing on the main resources, members of staff and their knowledge, and financial funds, of HE institutions. With regard to members of staff, academics are the main concern. With regard to their knowledge, all knowledge-related factors, including creation through research, sharing through teaching, were addressed in the value chain model. Financial funds are an important and often critical resource that plays a major role in determining the generic strategy and value chain analysis of an institution. For managing such resources, strategic management and strategic management provide useful techniques and practices, such as the value chain. The objective of this paper was to develop a value chain for the HE setting but it transpired as more appropriate to amend Groves et al.'s (1997) previously developed value chain model. It was amended in order to reflect academic staff as a critical success factor, which was expressed by the activity of academic recruitment. This newly developed model allows academics to theoretically engage with aspects that increase their own and their division's competitive advantage, and allows practitioners to consider developing a value chain for their institution in order to identify and/or develop competitive advantage. It was originally developed for a particular academic division but reflects the academic context more generally. The critical success factors staff, funding and time apply to all various academic disciplines, as transpired during the research. A difference in the application of the value chain model arises from the generic strategy chosen. The English case division's strategy was inclusive of a variety of subjects, so for instance offering Master degree courses that required very different courses from one programme to another, allowing for the division to have a special position in the market. This reflects their differentiation-based-on-quality strategy. The same is the case for Jordanian Institution Number 3. However, Institutions 1 and 2 that have chosen cost leadership focus on running programmes that are accessed by a large number of students, and for several programmes these students access largely the same courses with some variation only.

In addition to determining competitive advantage and being supportive of strategic management, the value chain model can be used to undertake cost analysis based on the example provided by Shank and Govindarajan (1992). This would be useful with the regard to trying to assign cost to individual activities but the information necessary to render a meaningful example would have to be collected as part of the annual, institutional or divisional, strategic planning and budgetary exercise. So an institutional or at least divisional commitment has to be made if the cost analysis for the value chain is to be undertaken. While the author of this article attempted to undertake a cost analysis, it was not a useful exercise as access to management accounting data was severely limited. What was available from the English division was not allowed to be published. From the Jordanian divisions, no financial information was available. Thus, practitioners have to make a conscious effort in utilising all available information and in some cases collect specific information, to undertake a costing of competitive advantage exercise.

For practical application in the HE context, the value chain analysis is deemed a useful tool for identifying critical success factors, core competences in order to develop inimitable competitive advantages, and generally getting a greater insight into the strategic and financial context of a division or institution. This study also illustrates how a model developed for one particular context, can be adapted to another context, in particular an adaptation from a private to public sector, profit to non-profit, and manufacturing to research and teaching situation. Furthermore, getting feedback from academics of a completely different environment helped to develop the model further, and helped to ascertain that the model extends beyond the realm of one particular division. As Shank and Govindarajan (1992) state, value chain analyses are not undertaken commonly, thus this study seeks to contribute a further illustration and identify the usefulness of this type of analysis in the academic environment.

Limitations of the study are that the model is inductively developed but not yet deductively applied. A further limitation is that not enough data was available to undertake a relevant cost analysis and to develop a set of relevant cost items and measures. In the case of applying a value chain, it would be important to at least cost activities, and for future studies, access to financial information should be negotiated before commencement of the study. For future research it would be interesting to see the model applied with the purpose to determine the generic strategy and competitive advantage of a division or institution. It would also be interesting to see the value chain model applied in various institutions and HE sector settings, and to undertake a detailed costing for competitive advantage analysis.

\section{References}

Anderson, S.W. (2007). Managing Costs and Cost Structure throughout the Value Chain: Research on Strategic Cost Management, Eds: Chapman, C., Hopwood, A and Shields, M., Handbook of Management Accounting Research, Vol. 2, Oxford: Elsevier, pp. 481 - 506

Avison, D., Lau, F., Myers, M.D., and Nilson, P.A. (1999). Action Research. Communications of the ACM, Vol. 42 No. 1, pp. 94-97. http://dx.doi.org/10.1145/291469.291479

Bardy, R. (2006). Management control in a business network: new challenges for accounting. Qualitative Research in Accounting \& Management, Vol. 3, No. 2, pp.161 - 181, http://dx.doi.org/10.1108/11766090610670686

Barney, J. (1991). Firm Resources and Sustained Competitive Advantage. Journal of Management, Vol. 17, No. 1, pp. 99 - 120. http://dx.doi.org/10.1177/014920639101700108

Barney, J., Wright, M., and Ketchen Jr., D.J. (2001). The resource-based view of the firm: Ten years of 1991. 
Journal of Management, Vol. 27, pp. 625 - 641. http://dx.doi.org/10.1177/014920630102700601

BBC (2010). Q\&A University funding. (9 December, 2010), [Online] Available: http://www.bbc.co.uk/news/education-11483638 (14 January 2011)

Bowman, C., and Toms, S. (2010). Accounting for competitive advantage: The resource-based view of the firm and the labour theory of value. Critical Perspectives on Accounting, Vol. 21, No. 3, pp. 183 - 194. http://dx.doi.org/10.1016/j.cpa.2008.09.010

Bromwich, M. (1990). The case for strategic management accounting: The role of accounting information for strategy in competitive markets. Accounting, Organizations and Society, Vol. 15, No. 1/2, pp. 3 - 25.

Cadez, S., and Guilding, C. (2007). Benchmarking the incidence of strategic management accounting in Slovenia. Journal of Accounting and Organizational Change, Volume 3, No. 2, 126-146.

Cinquini, L., and Tenucci, A. (2010). Strategic management accounting and business strategy: a loose coupling?, Journal of Accounting and Organizational Change, Vol. 6, No. 2, pp. 228 - 259.

Denscombe, M. (1998). The good research guide: for small-scale social research projects. Maidenhead (UK): Open University Press

DfES. (2003). The future of Higher Education. [Online] Available: http://www.dcsf.gov.uk/hegateway/strategy/hestrategy/foreword.shtml (03 July 2010)

DIUS. (2008). Innovation Anation, Anline] http://webarchive.nationalarchives.gov.uk/tna/t/http://www.dius.gov.uk/publications/scienceinnovation.pdf/ (20 July 2010)

Elloumi, F. (2004). Value chain analysis: a strategic approach to online learning. Theory and Practice of Online Learning, Eds: Anderson, T. and Elloumi, F., [Online] Available: http://cde.athabascau.ca/online_book/index.html, pp. $61-92$

Ferlie, E. (1992). The creation and evolution of quasi-markets in the public sector: a problem for strategic management. Strategic Management Journal, Vol. 13, pp. 79-97, http://dx.doi.org/10.1002\%2Fsmj.4250130907

Grant, R.M. (1991). The Resource-Based Theory of Competitive Advantage: Implications for Strategy Formulation. California Management Review; Vol. 33, No. 3, pp. 114-135,

Grimston, J. (2009). Plan for tuition fees to hit £7,000 a year, The Sunday Times (26 July 2009), [Online] Available: www.timesonline.co.uk/tol/life_and_style/education (13 August 2009)

Groves, R.E.V., Pendlebury, M.W., \& Stiles, D.R. (1997). A critical appreciation of the uses for strategic management thinking, systems and techniques in British Universities. Financial Accountability \& Management, Vol. 13, No. 4, pp. 293 - 312. http://dx.doi.org/10.1111/1468-0408.00040

Henry, A. (2011). Understanding Strategic Management, $2^{\text {nd }}$ edition. Oxford: Oxford University Press

Hussey, J., and Hussey, R. (1997). Business Research: a practical guide for undergraduate and postgraduate students. Basingstoke: Macmillan Press

Kaplan, R. S. (1998). Innovation action research: Creating new management theory and practice. Journal of Management Accounting Research, Vol. 10, pp. 89-118.

Kaplan, R.S. (1984). The evolution of management accounting. The Accounting Review, Vol. 59, pp. 390-418

Kraaijenbrink, J., Spender, J.C., and Groen, A.J. (2010). The Resource-based View: a review and assessment of its critiques. Journal of Management, Vol. $36, \quad$ No. $1, \quad$ pp. 349 - 372. http://dx.doi.org/10.1177/0149206309350775

Mintzberg, H. (1990). The design school: reconsidering the basic premises of strategic management. Strategic Management Journal, Vol. 11, No. 3, pp. 171-195. http://dx.doi.org/10.1002/smj.4250110302

Paul, D.A. (2005). Higher Education in Competitive Markets: Literature on Organizational Decline and Turnaround. The Journal of General Education, Vol. 54, No. 2, pp. 106 - 138. http://dx.doi.org/10.1353/jge.2005.0023

Porter, M . E. (1980). Competitive Strategy : Techniques for Analyzing Industries and Competitors. New York: The Free Press .

Porter, M.E. (1985) Competitive Advantage: Creating and Sustaining Superior Performance. New York: The Free Press .

Porter, M.E. (1990). Competitive Advantage of Nations. New York: The Free Press

Porter, M.E. (1991). Towards a Dynamic Theory of Strategy.Strategic Management Journal, Vol. 12 (Winter Special Issue), pp. 95-117.

Shank, J. K. (1989). Strategic cost management: New wine, or just new bottles?, Journal of Management Accounting Research, Vol. 1, pp. $47-65$.

Shank, J. K., and Govindarajan, V. (1992a). Strategic cost management: The value chain perspective. Journal of Management Accounting Research, Vol. 4, pp. 179 - 197.

Shank, J.K. (1996). Analysing technology investments - from NPV to strategic cost management. Management Accounting Research, Vol. 7, pp. 185 - 197. http://dx.doi.org/10.1006/mare.1996.0011 
Shank, J.K., and Govindarajan, V. (1992b). Strategic cost management and the value chain. Journal of Cost Management, Winter: pp. 5 - 21

Shank, J.K., and Govindarajan, V. (1993). Strategic Cost Management: the new tool for competitive advantage. New York: The Free Press

Simmonds, K. (1981). Strategic management accounting. Management Accounting (CIMA), April, pp. 26 - 29

Stringer, E.T. (1999). Action research, $2^{\text {nd }}$ edition. Thousand Oaks, CA: Sage

Tomkins, C., and Carr, C. (1996). Editorial: strategic management accounting. Management Accounting Research, Vol. 7, pp. 165-7.

Toms, S. (2010). Value, profit and risk: accounting and the resource-based view of the firm. Accounting, Auditing and Accountability Journal, Vol. 23, No. 5, pp. $647-670$ http://dx.doi.org/10.1108/09513571011054927

Von Alberti, L. (2003). The Value Chain in Higher Education, Unpublished Master Dissertation, University of Southampton, UK

Ward, K. (1992). Strategic Management Accounting. Oxford: Butterworth-Heinemann

Wilsdon, J. (2008). At last, real creative spark. The Times Higher (27 March 2008). [Online] Available: www.timeshighereducation.co.uk (13 August 2009)

Wilson R. M. S. (1995). Strategic Management Accounting, in Ashton et al (eds), Issues in Management Accounting, 2nd edition. PHI Englewood Cliffs (NJ).

Table 1. The composition of interviewees

\begin{tabular}{|l|l|l|l|l|}
\hline Interviewee & Gender & Position & Seniority & Nationality \\
\hline Academic staff member A & Male & $\begin{array}{l}\text { Professor, Director of Postgraduate } \\
\text { Taught Programmes }\end{array}$ & Senior & British \\
\hline Academic staff member B & Female & Lecturer & Junior & British \\
\hline Academic staff member C & Male & Professor, Director of Research & Senior & British \\
\hline Academic staff member D & Male & Professor, Head of School & Senior & British \\
\hline Academic staff member E & Male & $\begin{array}{l}\text { Professor, Director of Postgraduate } \\
\text { Research Programme }\end{array}$ & Senior & British \\
\hline Academic staff member F & Male & $\begin{array}{l}\text { Professor, Director of Undergraduate } \\
\text { Education }\end{array}$ & Senior & British \\
\hline Academic staff member G & Female & Assistant Professor & Senior & German \\
\hline Academic staff member H & Male & Professor, Head of Department & Senior & Jordanian \\
\hline Academic staff member I & Male & Assistant Professor, Vice-Dean & Senior & Jordanian \\
\hline Academic staff member J & Female & Assistant Professor & Junior & Jordanian \\
\hline Academic staff member K & Male & $\begin{array}{l}\text { Assistant Professor, previously Head of } \\
\text { Department }\end{array}$ & Senior & Jordanian \\
\hline Academic staff member L & Male & Lecturer & Senior & Jordanian \\
\hline Support staff member M & Female & Finance Officer & Senior & British \\
\hline Support staff member N & Female & Learning and Teaching Officer & Senior & British \\
\hline Student A & Female & Postgraduate Taught & & Greek \\
\hline Student B & Male & Undergraduate & Final year & British \\
\hline Student C & Female & Postgraduate Research & First year & Chinese \\
\hline Student D & Male & Postgraduate Taught & Second year & British \\
\hline Student E & Male & Undergraduate & Final year & Jordanian \\
\hline Student F & Female & Postgraduate Taught & Greek \\
\hline Student G & Male & Postgraduate Research & Spanish \\
\hline Student H & Fale & Postgraduate Taught & Postgraduate Taught & \\
\hline Student I & Male & Postgraduate Taught & & \\
\hline Student J & & & & \\
\hline
\end{tabular}




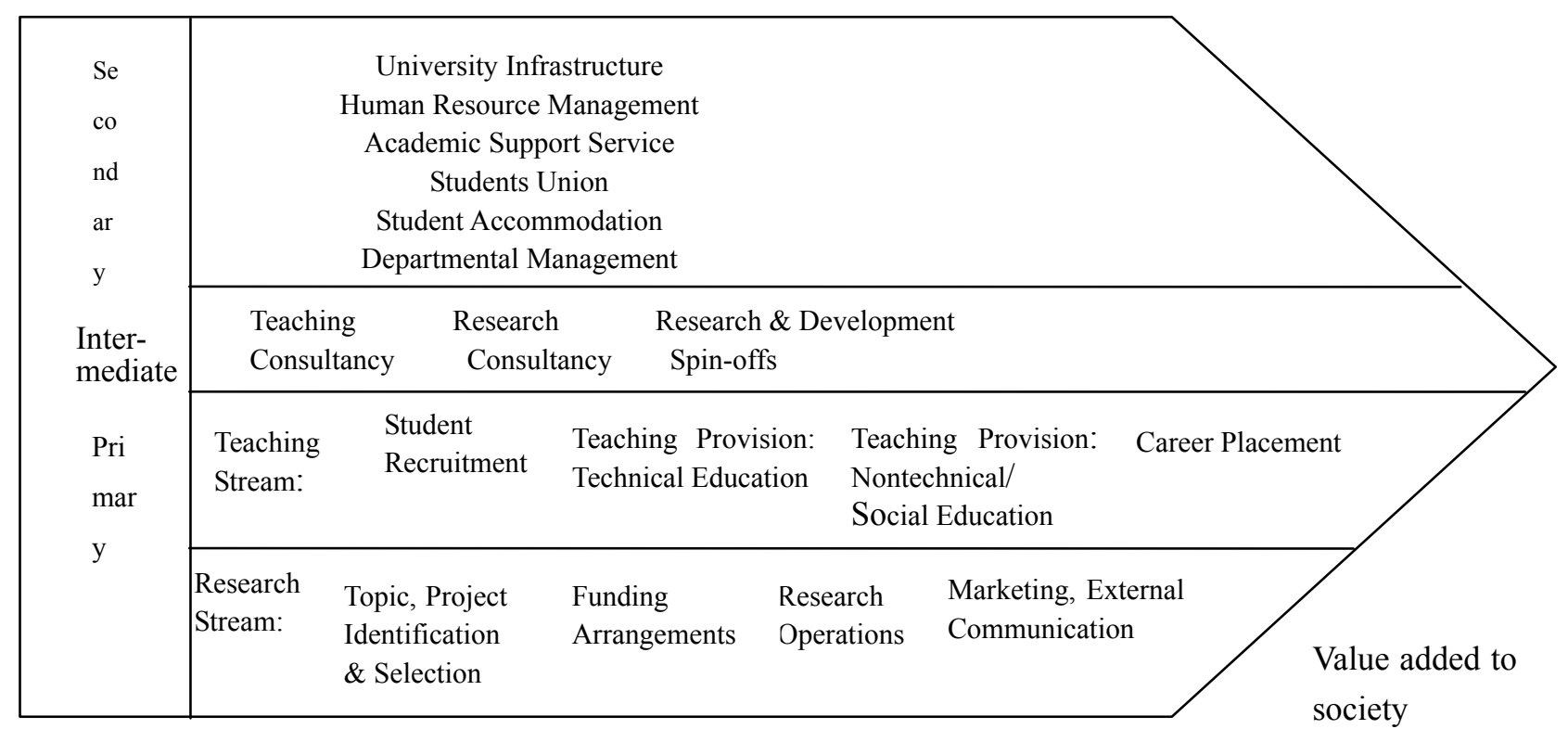

Figure 1. As adopted from Groves et al., 1997, p. 304

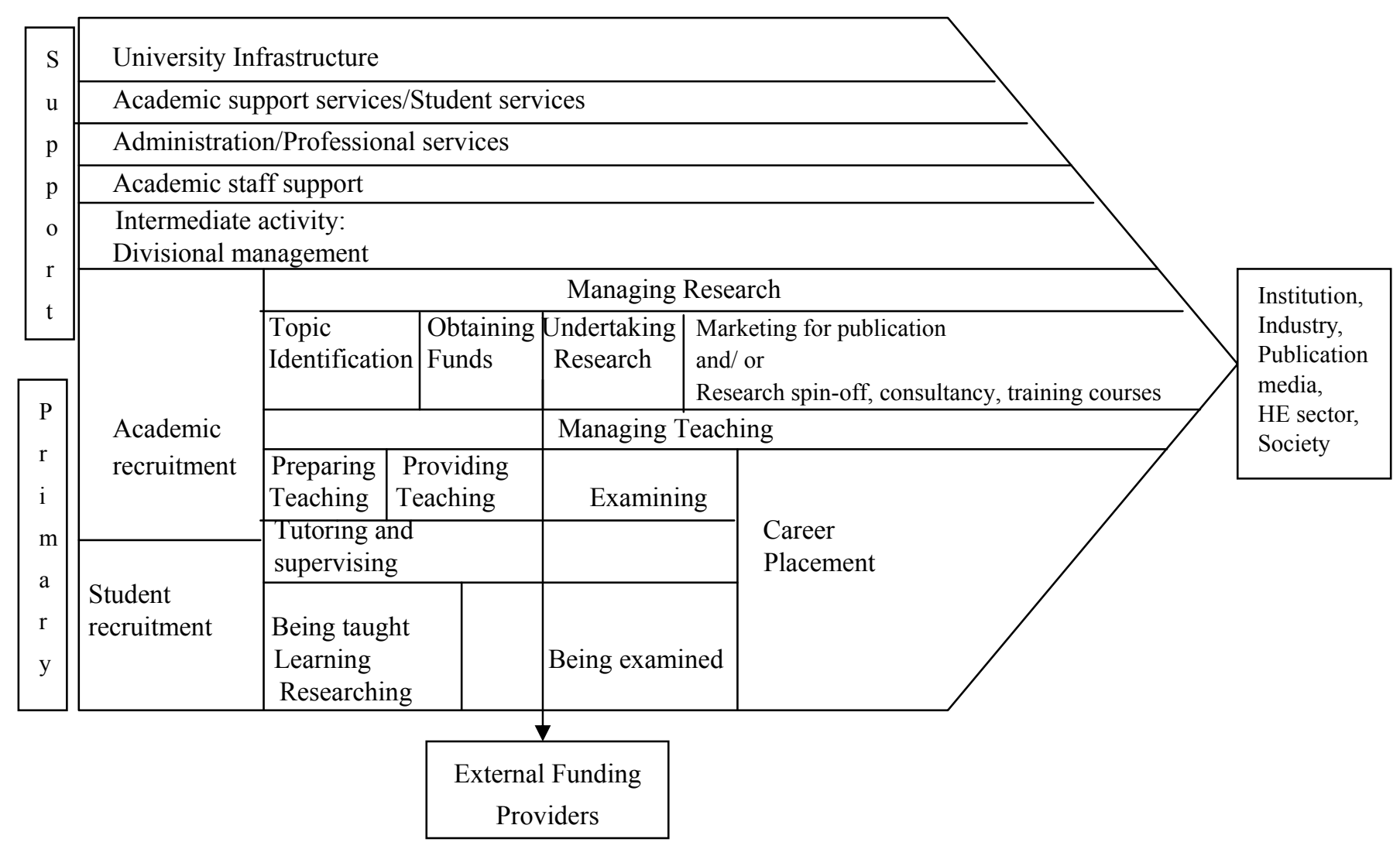

Figure 2. Value chain for Higher Education 